\title{
Evaluating ozone spatial distribution in Portugal using passive samplers
}

\author{
J. Monjardino, S. Mesquita, H. Tente, F. Ferreira, P. Gomes \\ \& N. Franco \\ Department of Sciences and Environmental Engineering, \\ Faculty of Sciences and Technology, New University of Lisbon, Portugal
}

\begin{abstract}
Tropospheric ozone is a pollutant of major concern in Portugal and in Europe, especially during summer and spring time. In Portugal, several studies and the analysis of air quality data series highlighted high ozone $\left(\mathrm{O}_{3}\right)$ levels inland. A study was carried out to assess the rural background stations representativeness area for $\mathrm{O}_{3}$. Monitoring campaigns were performed in the summer of 2005 within five Portuguese air quality management zones where critical levels are usually reached. $\mathrm{O}_{3}$ passive samplers (148 diffusive tubes, one-week exposure) as well as a mobile monitoring station were used. In relation to spatial $\mathrm{O}_{3}$ patterns, the studied air quality stations appear to be representative of the majority of their zones. Regarding the temporal representativeness, a trend was found for higher hourly $\mathrm{O}_{3}$ correlations between sites located both on a coastal territory axis and on an inland territory axis. Thus, it seems that similar geographical, topographical and meteorological conditions are a more significant factor to define the stations area of representativeness, rather then the proximity between locations.
\end{abstract}

Keywords: ozone, representativeness, air quality monitoring stations, diffusive sampling.

\section{Introduction}

Ozone $\left(\mathrm{O}_{3}\right)$ is a secondary pollutant formed in the atmosphere as a result of reactions between primary pollutants (ozone precursors), such as, nitrogen oxides (NOx) and volatile organic compounds (VOC), emitted largely by industry and road traffic. Besides the $\mathrm{O}_{3}$ formation processes there are also 
reactions promoting its destruction in a polluted atmosphere, by chemical titration with nitrogen monoxide (NO), in the nearby emission sources Airparif [1]. Thus, higher $\mathrm{O}_{3}$ concentration values are not measured necessarily near the precursors emission sources but occur, downwind, in the surrounding areas, in a few tens of kilometres away Airaq [2]. $\mathrm{O}_{3}$ is a photochemical pollutant reaching high concentrations especially during summer and spring time. The main meteorological variable that influences surface $\mathrm{O}_{3}$ concentrations is the temperature although wind speed, ultra-violet radiation, atmospheric stability, atmospheric moisture and long-range transport could also have a significant role in ozone formation Comrie [3]. Forest fires can also play a significant role on $\mathrm{O}_{3}$ generation, since VOC are released in the course of biomass combustion. Emissions from distant forest fires can contribute to regional accumulations of high $\mathrm{O}_{3}$ concentrations McKeen et al [4]. Another relevant factor is the altitude effect, where an increase of $\mathrm{O}_{3}$ levels is associated to a major photochemical production at higher altitudes Blankinship [5].

A monitoring station provides air quality data representative of a certain area around the station. According to the EUROAIRNET criteria the area in which the concentration does not differ from the concentration measured at the station by more than $20 \%$ is the area of representativeness of the station Larssen et al [6]. Passive sampling technique is frequently used to assess spatial distribution of air pollution, covering large areas, as Costabile et al [7] evidenced. Passive monitoring (by using diffusive samplers) combined with active monitoring (by using existing air quality monitoring stations and mobile units) is an approach that allows one to address the question of how representative the site and time period of air quality measurements actually can be Vardoulakis et al [8].

The third Daughter Directive 2002/3/EC on ozone in ambient air establishes an information threshold which means a level beyond which there is a risk to human health from brief exposure for particularly sensitive population and at which up-to-date information is necessary. In Portugal the air quality monitoring network, detects every year in summer and spring period some hundreds of exceedances to the information threshold, about $40 \%$ of them occur in the recently installed rural stations. Some of these stations registered the highest number of exceedances. Recent Portuguese studies demonstrate that high levels of $\mathrm{O}_{3}$ affect more the inland territory rather than coastal areas. It was also been evidenced that orographycal characteristics, altitude, and the amount of solar radiation seemed to be correlated with the $\mathrm{O}_{3}$ concentrations distribution (Ferreira et al [9], Mesquita et al [10]). The assessment of this stations area of representativeness, within the air quality management zones MAOT/DGA, UNL/FCT/DCEA [11] created in the context of the Air Quality Framework Directive, and the exposed population is for these reasons a major important issue in Portugal.

\section{Methodology}

The defined methodology for representativeness analysis was applied to the following zones and stations: Norte Interior zone (Lamas de Olo station), Centro 
Interior zone (Fundão station), Vale do Tejo e Oeste zone (Chamusca station), Alentejo Interior zone (Terena station) and Algarve zone (Cerro station), which are represented in Figure 1.

The methods chosen to measure ozone concentrations were both passive and active sampling. As passive samplers, Radiello diffusive tubes were placed in 148 locations (about 30 per zone) in a grid of $20 \mathrm{~km} \mathrm{x} 20 \mathrm{~km}$ in the vicinity of the station, and $40 \mathrm{~km}$ x $40 \mathrm{~km}$ within the zone. As active sampler, one mobile station equipped with an automatic analyser operating with a reference technique was placed in one location far from the fixed station in each zone during each campaign.

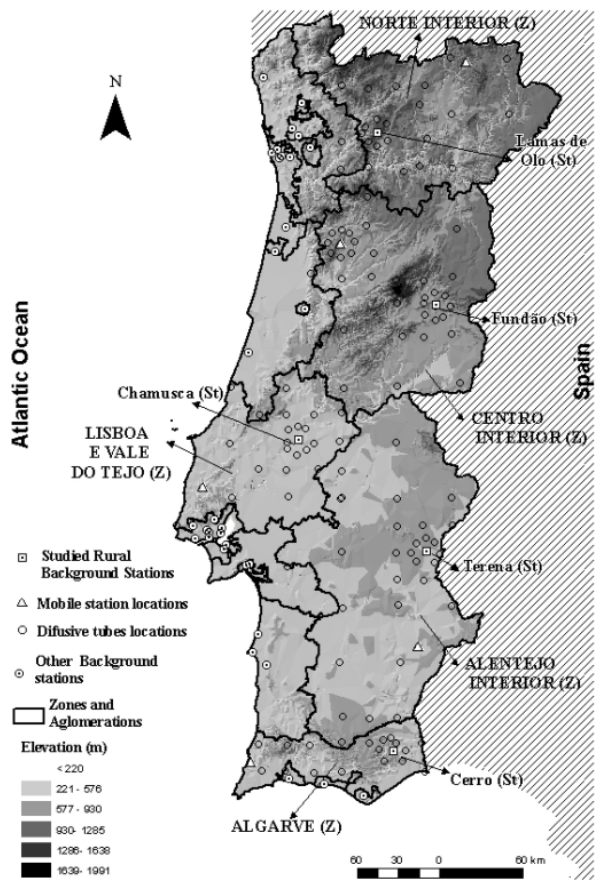

Figure 1: Delimitation of the Portuguese zones and agglomerations, and location of the studied rural stations, mobile station, diffusive sampling points and other national monitoring stations.

In terms of Quality Assurance/Quality Control (QA/QC) the procedures expressed in the Guidance Report on Preliminary Assessment EEA [12] for indicative measures were followed, and can be summarized as follows:

- $\quad$ keeping non exposed tubes in each campaign;

- expose several tubes in the same location (3 to 5) to evaluate the precision (repeatability of multiple measurements of the same event);

- expose several tubes in the fixed and mobile station location to evaluate the accuracy (truth of a measurement). 
These procedures allowed the determination of uncertainty (degree of accuracy and precision of data) level of the campaign results.

Due to the financial, equipment, and time limitations, it was only performed a one-week campaign per zone, between 19-7-2005 and 14-9-2005. The chemical analysis of Radiello diffusive tubes were done in the Environment Reference National Laboratory, following the Radiello proceedings.

The data series analysis and interpretation included an uncertainty analysis for each campaign; mapping results obtained in each sampling spot and interpolation to obtain a continuous surface, using the Ordinary Kriging interpolation method (ArcGIS ${ }^{\circledR} 9.1$ - extension Geostatistical Analyst); collecting ozone production related data: zones altimetry, meteorology during the campaigns and data on forest fires, to support the interpretation; and, evaluation of the area of representativeness of each station within the zone, according to the EUROAIRNET Criteria.

\section{Results and discussion}

The QA/QC evaluation included the analysis of precision, accuracy and uncertainty.

The level of repeatability of diffusive sampler measures can be evaluated through the coefficient of variation $(\mathrm{CV})$, defined as the ratio of the standard deviation to the mean. A satisfactory $\mathrm{CV}$, meaning low dispersion of results from samplers placed in the same site, would be less than $10 \%$ Garcia-Fouqué et al [13]. As it can be observed in Table 1, the CV didn't vary over $12 \%$ showing an acceptable precision.

In terms of accuracy levels, a good linearity of responses was obtained between the two monitoring methods, with a high coefficient of determination $\left(\mathrm{R}^{2}=91\right)$. The ozone concentrations measured by diffusive samplers exhibit a slight positive bias (over-read) in relation to those obtained by automatic analysers (from monitoring stations and the mobile unit).

Uncertainty is defined by the European Standard EN 13528-1:2002 (that specifies general performance requirements for diffusive samplers used for the determination of the concentration of gases in ambient air) as it follows, eqn (1):

$$
\text { Uncertainty }(\%)=\frac{\left|x-x_{\text {ref }}\right|+2 S}{x_{\text {ref }}} \times 100
$$

where $\bar{x}$ represents the average of the passive samplers repeated measurements, $x_{\text {ref }}$ is the value of the concentration measured by active monitoring, and $S$ is the passive samplers repeated measurements standard deviation. When performing diffusive sampling campaigns a maximum measurements uncertainty of $\pm 30 \%$ is proposed, as a data quality requirement EEA [12]. As presented in Table 1, considerable levels of uncertainty were obtained (from $16 \%$ to $46 \%$ ).

The analysis of ozone concentrations, obtained in the five studied zones, and the information collected on factors influencing its chemistry, allowed to get a global picture of the conditions verified during the monitoring campaigns. 
Table 1: Ozone concentrations measured by passive and active sampling $\left(\mu \mathrm{g} / \mathrm{m}^{3}\right)$, at five Portuguese zones, standard deviation, coefficient of variation, and uncertainty associated to the passive sampling method

\begin{tabular}{|c|c|c|c|c|c|c|}
\hline \multirow{2}{*}{ Zone } & \multirow{2}{*}{ Location } & \multicolumn{3}{|c|}{ Passive samplers } & \multirow{2}{*}{$\begin{array}{c}\begin{array}{c}\text { Active } \\
\text { samplers }\end{array} \\
\mathrm{O}_{3}\left(\mu \mathrm{g} / \mathrm{m}^{3}\right)\end{array}$} & \multirow{2}{*}{$\begin{array}{c}\text { Uncertainty } \\
(\%)\end{array}$} \\
\hline & & $\begin{array}{c}\text { Nr. } \\
\text { samplers }\end{array}$ & $\mathrm{O}_{3}\left(\mu \mathrm{g} / \mathrm{m}^{3}\right)$ & CV $(\%)$ & & \\
\hline \multirow{2}{*}{$\begin{array}{l}\text { Norte } \\
\text { Interior }\end{array}$} & OLO-AQMS & 3 & 78 & 12 & 104 & 43 \\
\hline & VIN-MMU & 2 & 92 & 0 & 79 & 16 \\
\hline \multirow{2}{*}{$\begin{array}{l}\text { Centro } \\
\text { Interior }\end{array}$} & FUN-AQMS & 5 & 63 & 12 & 59 & 32 \\
\hline & FORN-MMU & 4 & 61 & 4 & 75 & 24 \\
\hline \multirow{2}{*}{ VTO } & CHA-AQMS & 3 & 77 & 7 & 74 & 18 \\
\hline & TUR-MMU & 3 & 81 & 4 & 60 & 46 \\
\hline \multirow{2}{*}{$\begin{array}{l}\text { Alentejo } \\
\text { Interior }\end{array}$} & TER-AQMS & 3 & 66 & 6 & 51 & 46 \\
\hline & ENX-MMU & 3 & 64 & 7 & 83 & 34 \\
\hline \multirow{2}{*}{ Algarve } & CER-AQMS & 3 & 130 & 5 & 100 & 43 \\
\hline & ALJ-MMU & 2 & 124 & 5 & 102 & 33 \\
\hline
\end{tabular}

CV-Coefficient of variation; VTO - Vale do Tejo e Oeste; AQMS - air quality monitoring station; MMU - mobile monitoring unit; OLO-Lamas de Olo; VIN-Vinhais; FUN-Fundão; FORN-Fornelo do Monte; CHA-Chamusca; TUR-Turcifal; TER-Terena; ENX-Enxoé; CER Cerro; ALJ -Aljezur.

The Lamas de Olo monitoring station, located in the Norte Interior zone, registered the highest $\mathrm{O}_{3}$ levels, and Terena monitoring station, sited in Alentejo Interior zone, recorded the lowest. The $\mathrm{O}_{3}$ daily averages presented a high correlation with the maximum daily temperatures $(77 \%, 69 \%$ and $68 \%$ in Vale do Tejo e Oeste, Norte Interior and Centro Interior zones). The lowest $\mathrm{O}_{3}$ oneweek average concentration was obtained for all monitoring stations during the Norte Interior and Centro Interior campaigns. Concerning passive monitoring the highest $\mathrm{O}_{3}$ levels were measured in Algarve.

The 2005 summer had average temperatures (minimum, medium and maximum) higher than usual, and more than one heat wave were registered IM [14]. Had also been registered fires devastating a total of $3 \%$ of the Portuguese continental territory MADRP/DGRF [15]. In the period in which the Algarve and Alentejo campaigns were carried out MODIS satellite imagery allowed to observe the gas plume crossing the monitoring area, with possible influence on ozone chemistry.

The relationship between altitude of measurements and ozone concentration results was stronger in the Norte campaign (coefficient of determination $\mathrm{R}^{2}=50 \%$ ). For the other studied zones the coefficients of determination varied from $22 \%$ to $46 \%$, showing that, although altitude has some relation with ozone concentrations, there are other factors conditioning its levels.

Within respect to the temporal representativeness assessment a correlation matrix was produced for ozone hourly concentrations measured in all Portuguese rural background monitoring stations, from July, $1^{\text {st }}$ to September, $30^{\text {th }} 2005$ (Table 2). Table 3 summarizes correlation coefficients obtained by comparing the ozone hourly concentrations measured in all rural background monitoring 
stations with the mobile unit data sets, for each campaign period. Some general considerations about these results are as follows:

- stations from Norte Interior zone have a good level of common information (correlation coefficient of 78\%), but in general are less correlated with stations from the other zones;

- stations from Centro zone are weakly correlated between them;

- stations from Vale do Tejo e Oeste, Centro Litoral and Alentejo Litoral zones, located near the Atlantic coast, are well correlated between them, and stations from the inland territory, as Fundão, Terena and Cerro also present good correlation levels;

- it seems that temporal correlation is stronger for locations across the country based on geographical characteristics such as inland/coastal features rather than the linear distance between measurement sites; an exception appears for stations located in Norte Interior and Centro zones, with specific characteristics in terms of elevations and slopes on land surface.

The analysis of representativeness for rural stations, within each zone, is represented in Figure 2. The ozone concentrations obtained by passive sampling, as points and areas, are presented in intervals of variation (in percentage) in relation to the rural station concentration. Table 4 provides additional information regarding the percentage of monitoring spots and areas that can be represented by the air quality station, and also a measure of spatial patterns error, obtained using geostatistics to interpolate sampling points measurements (Ordinary Kriging method).

Table 2: Correlation matrix of ozone hourly concentrations measured in all Portuguese rural background monitoring stations (from 1-7-2005 to 30-9-2005).

\begin{tabular}{|c|c|c|c|c|c|c|c|c|c|}
\hline \multirow[t]{2}{*}{ Zone } & & $\begin{array}{c}\text { Norte } \\
\text { L. }\end{array}$ & $\begin{array}{c}\text { Norte } \\
\text { I. }\end{array}$ & $\begin{array}{c}\text { Centro } \\
\text { L. }\end{array}$ & $\begin{array}{c}\text { Centro } \\
\text { I. }\end{array}$ & VTO & $\begin{array}{l}\text { Alent. } \\
\text { L. }\end{array}$ & $\begin{array}{c}\text { Alent. } \\
\text { I. }\end{array}$ & Alg. \\
\hline & Station & $\mathrm{MNH}$ & OLO & ERV & FUN & CHA & MVE & TER & CER \\
\hline Norte L. & $\mathrm{MNH}$ & 1 & & & & & & & \\
\hline Norte I. & OLO & 0,74 & 1 & & & & & & \\
\hline Centro L. & ERV & 0,54 & 0,45 & 1 & & & & & \\
\hline Centro I. & FUN & 0,40 & 0,53 & 0,57 & 1 & & & & \\
\hline VTO & $\mathrm{CHA}$ & 0,67 & 0,58 & 0,73 & 0,62 & 1 & & & \\
\hline Alent. L. & MVE & 0,44 & 0,37 & 0,74 & 0,62 & 0,71 & 1 & & \\
\hline Alent. I. & TER & 0,42 & 0,45 & 0,63 & 0,63 & 0,69 & 0,74 & 1 & \\
\hline Alg. & CER & 0,55 & 0,59 & 0,53 & 0,63 & 0,70 & 0,61 & 0,70 & 1 \\
\hline \multicolumn{10}{|c|}{$\begin{array}{l}\text { L-Litoral; I-Interior; VTO-Vale do Tejo e Oeste; Alent-Alentejo; Alg-Algarve; MNH-Sra do } \\
\text { Minho; OLO-Lamas de Olo; ERV-Ervedeira; FUN-Fundão; CHA-Chamusca; MVE-Monte } \\
\text { Velho; TER-Terena; CER -Cerro; }\end{array}$} \\
\hline \multicolumn{6}{|c|}{ Correlation coefficient (abslotute value): $\square 0,30-0,50 ; \quad$} & \multicolumn{4}{|c|}{$>=0,70$} \\
\hline
\end{tabular}

The area or points with a variation of less than $20 \%$ from the station concentration were considered within the area of representativeness of the station (EUROAIRNET criteria Larssen et al [6]). The results indicate that, during the campaigns periods, for all the zones in analysis, the respective rural stations are 
representative of both the majority of rural points (between $61 \%$ and $75 \%$ ) and practically all rural area within zones (between $70 \%$ and 100\%). The higher percentage of representative areas in comparison with rural points is mainly due to the spatial modelling patterns that tend to smooth the points with concentrations not consistent with the neighbourhood. The maps also show that the distance from the station is not the most important factor to define the area of representativeness. The closest points are not always the most similar and well correlated. Other factors as territorial (land use and topography) and meteorological characteristics seem to have a more important role.

Table 3: Correlation coefficients of ozone hourly concentrations measured in all Portuguese rural background monitoring stations and in the mobile monitoring unit, for each campaign period.

\begin{tabular}{ll|l|l|l|l|l}
\hline \multicolumn{1}{c}{ Zone } & $\begin{array}{c}\text { Norte } \\
\text { Int. }\end{array}$ & $\begin{array}{c}\text { Centro } \\
\text { Int. }\end{array}$ & VTO & $\begin{array}{c}\text { Alent. } \\
\text { Int. }\end{array}$ & Algarve \\
\cline { 2 - 7 } & AQMS & VIN & FORN & TUR & ENX & ALJ \\
\hline Norte Int. & OLO & 0,78 & 0,89 & 0,68 & 0,35 & 0,34 \\
\hline Norte Lit. & MNH & 0,50 & 0,84 & 0,69 & 0,37 & 0,34 \\
\hline Centro Int. & FUN & 0,70 & 0,50 & 0,61 & 0,81 & 0,35 \\
\hline Centro Lit. & ERV & 0,57 & 0,61 & 0,80 & 0,64 & 0,50 \\
\hline VTO & CHA & 0,74 & 0,89 & 0,66 & 0,67 & 0,73 \\
\hline Alent. Int. & TER & 0,67 & 0,78 & 0,54 & 0,72 & 0,53 \\
\hline Alent. Lit. & MVE & 0,68 & 0,65 & NA & 0,71 & 0,75 \\
\hline Algarve & CER & 0,73 & 0,80 & 0,53 & 0,70 & 0,45 \\
\hline AQMS - Air Quality Monitoring Station; MMU - Mobile Monitoring Unit; Lit-Litoral; Int- \\
Interior; Alnt-Alentejo; VTO-Vale do Tejo e Oeste; MNH-Sra do Minho; OLO-Lamas de Olo; \\
ERV-Ervedeira; FUN-Fundão; CHA-Chamusca; MVE-Monte Velho; TER-Terena; CER - \\
Cerro; VIN-Vinhais; FORN-Fornelo do Monte; TUR-Turcifal; ENX-Enxoé; ALJ -Aljezur; \\
NA- Non available data for this period; Correlation coefficient within the same zone $\square$. \\
\hline
\end{tabular}

Table 4: $\quad$ Percentage of monitoring sampling sites represented by the station and areas of representativeness of each station (where the concentration variation regarding the station is less than $20 \%$ ), and mapping error.

\begin{tabular}{l|l|l|l|l}
\hline \multicolumn{1}{c|}{ Zone } & $\begin{array}{c}\text { Station } \\
\text { Location }\end{array}$ & $\begin{array}{c}\text { Monitoring locations } \\
\text { represented by the } \\
\text { station (\%) }\end{array}$ & $\begin{array}{c}\text { Zone area } \\
\text { represented by the } \\
\text { station (\%) }\end{array}$ & $\begin{array}{c}\text { Mapping (ordinary } \\
\text { kriging method) } \\
\text { error }\end{array}$ \\
\hline Norte Int. & OLO & $69 \%$ & $90 \%$ & $10 \%$ \\
\hline Centro Int. & FUN & $61 \%$ & $100 \%$ & $13 \%$ \\
\hline VTO & CHA & $67 \%$ & $95 \%$ & $13 \%$ \\
\hline Alentejo Int. & TER & $75 \%$ & $77 \%$ & $12 \%$ \\
\hline Algarve & CER & $64 \%$ & $70 \%$ & $10 \%$ \\
\hline
\end{tabular}

(1) Normalized Root Mean Squared Error $=\left(\Sigma\left(\mathrm{x}_{\text {Mod }}-\mathrm{X}_{\mathrm{Obs}}\right)^{2}\right)^{1 / 2} /$ Mean $\left(\mathrm{x}_{\mathrm{Obs}}\right)$; Int-Interior; VTO-Vale do Tejo e Oeste; OLO-Lamas de Olo; FUN-Fundão; CHA-Chamusca; TER-Terena; CER-Cerro. 


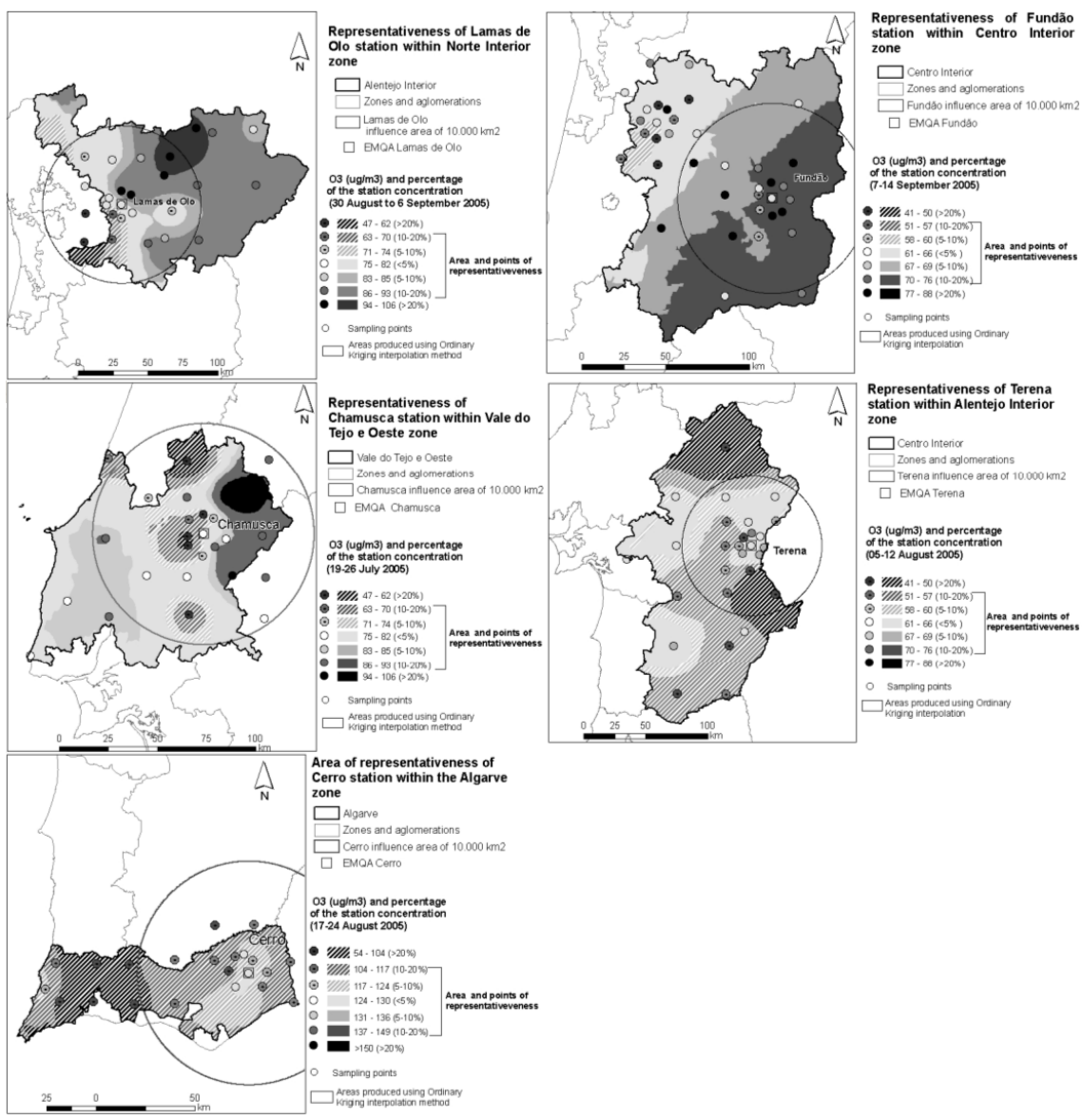

Figure 2: Area of representativeness of rural background stations within the zones in study.

In the analysis of these results one must take into account that for each zone only one week was measured, thus to obtain a more reliable picture the campaigns should be repeated covering at least $10 \%$ of the Summer and Spring periods (according to the ozone Daughter Directive 2002/3/EC).

\section{Conclusions}

A combination of passive monitoring (by using ozone diffusive samplers) and active monitoring (by using existing air quality monitoring stations and one mobile unit) has proved to be an efficient approach to address the question of how representative are the Portuguese rural background stations measurements.

The evaluation of the temporal representativeness was based on the hourly $\mathrm{O}_{3}$ correlation matrixes gathered from a mobile monitoring unit and from rural 
background monitoring network data sets. The results revealed higher temporal correlations between sites located inside a coastal territory axis and between sites located within an inland territory axis, showing that one important factor for temporal representativeness is sea proximity combined with orography.

Despite ozone concentrations obtained during these campaigns reflect a particular situation occurring in a specific period of time, air quality monitoring stations appear to be spatially representative of the great majority of each zone where they are located. This means that, for each studied zone, concentrations (obtained by interpolation of passive monitoring results) did not differ by more than $20 \%$ from the ones measured in rural background monitoring stations.

As a major finding of this study, it seems the proximity between sampling locations is not the most significant factor for the estimation of the area of representativeness for rural background stations. Geographical characteristics such as sea proximity, topographical features and meteorological conditions seem to be much better predictors for this end.

\section{Future developments}

A wider sampling period would be desirable in order to obtain more comprehensive data sets and a more reliable general picture of rural background air quality monitoring stations representativeness.

\section{Acknowledgements}

The authors would like to acknowledge funding for this study provided by the Portuguese Environment Institute. A word of gratitude should also be sent to the technicians of Regional Authorities (CCDR-Norte, CCDR-Centro, CCDR-LVT, CCDR-Alentejo, and CCDR-Algarve) for their valuable suggestions in the selection of sampling locations in their jurisdiction regions. The field campaigns covered a large area of the Portuguese territory and it would not be possible to manage it without the strong commitment of all the field teams.

\section{References}

[1] Airparif, Etude de la distribution spatiale des niveaux moyens d'ozone en période estivale dans le secteur de Rambouillet et dans la zone rurale sudouest de l'Ile-de-France, Airparif, Paris, 2001.

[2] Airaq, L'ozone en Aquitaine: cartographie et bilan estival. Rapport n. ${ }^{\circ}$ ET/CA/03/03, Airaq, France, 2003.

[3] Comrie, A.C., Comparing Neural Networks and Regression Models for Ozone Forecasting, Journal of Air \& Waste Man. Assoc., 47, 653-663, 1997.

[4] McKeen, S.A., Wotawa, G., Parrish, D.D., Holloway, J.S., Buhr, M.P., Hübler, G., Fehsenfeld, F.C. \& Meagher, J.F., Ozone production from 
Canadian wildfires during June and July 1995, J. Geophys. Res., Vol. 107, NO. D14, 4192, 10.1029/2001 JD000697, 2002.

[5] Blankinship, D.J., A Discussion of the Spatial and Temporal Variability of Ozone Concentrations along the Front Range of Colorado, Univ. of Colorado, USA, 1996.

[6] Larssen, S., Sluyter, R. \& Helmis, C., Criteria for EUROAIRNET - The EEA Air Quality Monitoring and Information, Tec. Report $\mathrm{n}^{\mathrm{o}}$. 12, European Environment Agency, Copenhagen, 1999.

[7] Costabile, F., Desantis, F., Hong, W., Liu, F., Salvatori, R., Wang, F. \& Allegrini, I., Representativeness of Urban Highest Polluted Zones for Sitting Traffic-Oriented Air Monitoring Stations in a Chinese City, JSME International Journal, Series B, Vol. 49, №. 1, pp. 35-41, 2006.

[8] Vardoulakis, S., Gonzalez-Flesca, N., Fisher, E.A.F. \& Pericleous, K., Spatial variability of air pollution in the vicinity of a permanent monitoring station in central Paris, Elsevier: Atm Environment, 39, 2725-2736, 2005.

[9] Ferreira, F., Tente, H., Torres, P., Mesquita, S., Santos, E., Jardim, D. \& Esgalhado, F., Background levels of sulphur dioxide, nitrogen dioxide and ozone in Portugal, Conf. Proceedings of International Conference Measuring Air Pollutants by Diffusive Sampling, Montpellier, France, 26-28 Sep, 2001.

[10] Mesquita, S., Ferreira, F., Tente, H. \& Torres, P., Using systematic diffusive sampling campaigns and geostatistics to map air pollution in Portugal. Conf. Proceedings of GeoENV2004 5th European Conference on Geostatistics for Environmental Applications, Centre for Hydrogeology, University of Neuchâtel, Switzerland, October 13-15, 2004.

[11] MAOT/ DGA, UNL/ FCT/ DCEA, Delimitação de zonas e aglomerações para avaliação da qualidade do ar em Portugal, DGA, Alfragide, ISBN: 972-8419-70-8, 2001.

[12] EEA, Guidance Report on Preliminary Assessment under EC Air Quality Directives, Tec. Rep. 11, Copenhagen, 1998.

[13] Garcia-Fouqué, S., Plaisance, H., Houdret, J.L., Mathé, F., Galloo, J.C. \& Guillermo, R., Performances des tubes à diffusion pour la mesure de l'ozone, du dioxyde d'azote et du dioxyde de soufre dans l'air ambiant, Pollution Atmosphérique, Juillet-Septembre 1999, pp. 89-96, 1999.

[14] IM, Informação Climática Agosto de 2005, [online] Available from: http://www.meteo.pt/pt/clima/info_clima/clim_informac.jsp, [cited 1 January 2007].

[15] MADRP/DGRF Incêndios Florestais Relatório de 2005, [online] Available from: http://www.dgrf.min-agricultura.pt/v4/dgf /pub.php?ndx=2271, [cited 1 January 2007]. 